\title{
New Cytotoxic Constituents from the Formosan Soft Corals Clavularia viridis and Clavularia violacea
}

\author{
Chang-Yih Duh,,$^{, \dagger}$ Ali Ali H. El-Gamal, ${ }^{\dagger, \neq}$ Chih-J u Chu, ${ }^{\dagger}$ Shang-Kwei Wang, ${ }^{\S}$ and Chang-Feng Dai ${ }^{\perp}$ \\ Department of Marine Resources, National Sun Yat-sen University, Kaohsiung, Taiwan, Department of Microbiology, \\ Kaohsiung Medical University, Kaohsiung, Taiwan, and Institute of Oceanography, National Taiwan University, \\ Taipei, Taiwan, Republic of China
}

Received April 19, 2002

\begin{abstract}
Three new cytotoxic prostanoids, claviridenone $E-G(\mathbf{1}-\mathbf{3})$, and three new cytotoxic steroids, stol oniferone E-G (4-6), were isolated from the methylene chloride solubles of the Formosan soft coral Clavularia viridis. A cytotoxic cembranoid, claviolide (7), was isolated from the methylene chloride solubles of the Formosan soft coral Clavularia violacea. The structures were elucidated by 1D and 2D NMR spectral analysis, and their cytotoxicity against selected cancer cells was measured in vitro.
\end{abstract}

The genus Clavularia has afforded many types of bioactive prostanoids, terpenoids, and steroids. ${ }^{1}$ As part of our search for bioactive substances from marine organisms, the Formosan soft corals Clavularia viridis Quoy and Gaimard (class Anthozoa, subclass Octocorallia, order Stolonifera) as well as C. violacea Quoy and Gaimard were studied because their $\mathrm{CH}_{2} \mathrm{Cl}_{2}$ extracts showed significant cytotoxicity against A549 (human lung adenocarcinoma), HT-29 (human colon adenocarcinoma), and P-388 (mouse lymphocytic leukemia) cell cultures as determined by standard procedures. ${ }^{2,3}$ Bioassay-guided fractionations resulted in the isolation of three new cytotoxic prostanoids, claviridenone $E-G(\mathbf{1}-\mathbf{3})$, and three new cytotoxic steroids, stoloniferone $E-G(\mathbf{4}-\mathbf{6})$, from $C$. viridis as well as a new cytotoxic cembranoid, claviolide (7), from C. violacea.

\section{Results and Discussion}

Compound $\mathbf{1}$ was shown to have a molecular formula of $\mathrm{C}_{23} \mathrm{H}_{32} \mathrm{O}_{5}$ as indicated by HREIMS and NMR data. The IR spectrum of 1 showed absorption due to acetate ester (1735, $1235 \mathrm{~cm}^{-1}$ ) and $\alpha, \beta$-unsaturated cyclopentenone (1705 $\mathrm{cm}^{-1}$ ) functionalities. The presence of a cross-conjugated system in 1, corresponding to that of the clavulones, ${ }^{4}$ was demonstrated by UV absorption at $226(\log \epsilon 3.88)$ and 290 $(\log \epsilon 4.04) \mathrm{nm}$. The ${ }^{13} \mathrm{C}$ NMR and DEPT spectrum exhi bited 23 carbon resonances which were attributable to two methyls ( $\delta 21.4 \mathrm{q}$ and $14.1 \mathrm{q}$ ), one methoxyl ( $\delta 51.6 \mathrm{q}$ ), one ketone carbonyl ( $\delta 193.9 \mathrm{~s}$ ), two ester carbonyls ( $\delta 173.6$ and $169.4 \mathrm{~s}$ ), eight sp ${ }^{3}$ methylene $(\delta 33.3 \mathrm{t}, 23.9 \mathrm{t}, 32.7 \mathrm{t}$, $35.7 \mathrm{t}, 27.5 \mathrm{t}, 29.1 \mathrm{t}, 31.6 \mathrm{t}, 22.6 \mathrm{t})$, seven $\mathrm{sp}^{2}$ methines ( $\delta$ $146.5 \mathrm{~d}, 125.4 \mathrm{~d}, 131.4 \mathrm{~d}, 134.8 \mathrm{~d}, 157.5 \mathrm{~d}, 121.3 \mathrm{~d}, 135.3$ d), one $\mathrm{sp}^{2}$ quaternary carbon ( $\delta 134.0 \mathrm{~s}$ ), and one $\mathrm{sp}^{3}$ quaternary carbon ( $\delta 85.6 \mathrm{~s}$ ) (Table 1 ). The ${ }^{1} \mathrm{H}$ NMR spectrum of $\mathbf{1}$ disclosed five ol efinic protons in the crossconjugated system at $\delta 6.22(1 \mathrm{H}, \mathrm{dt}, J=7.2,15.0 \mathrm{~Hz}, \mathrm{H}-5)$, $6.41(1 \mathrm{H}, \mathrm{d}, \mathrm{J}=6.0 \mathrm{~Hz}, \mathrm{H}-10), 6.54(1 \mathrm{H}, \mathrm{dd}, \mathrm{J}=11.7,15.0$ $\mathrm{Hz}, \mathrm{H}-6), 6.92(1 \mathrm{H}, \mathrm{d}, \mathrm{J}=11.7 \mathrm{~Hz}, \mathrm{H}-7), 7.48(1 \mathrm{H}, \mathrm{d}, \mathrm{J}=$ $6.0 \mathrm{~Hz}, \mathrm{H}-11)$; two olefinic protons on a carbon-carbon double bond at $\delta 5.17$ and $5.50 \mathrm{~m}$; and a terminal methyl at $\delta 0.88\left(3 \mathrm{H}, \mathrm{t}, J=6.9 \mathrm{~Hz}, \mathrm{H}_{3}-20\right)$. The analysis of the ${ }^{1} \mathrm{H}-{ }^{1} \mathrm{H}$ COSY spectrum (Figure 1 ) reveal ed a sequence of

* To whom correspondence should be addressed. Tel: 886-7-525-2000 ext. 5036. Fax: 886-7-525-5020. E-mail: yihduh@mail.nsysu.edu.tw.

+ National Sun Yat-sen University.

₹ On leave from Faculty of Pharmacy, Mansoura University, Egypt.

$\S$ Kaohsiung Medical University.

${ }^{\perp}$ National Taiwan University.
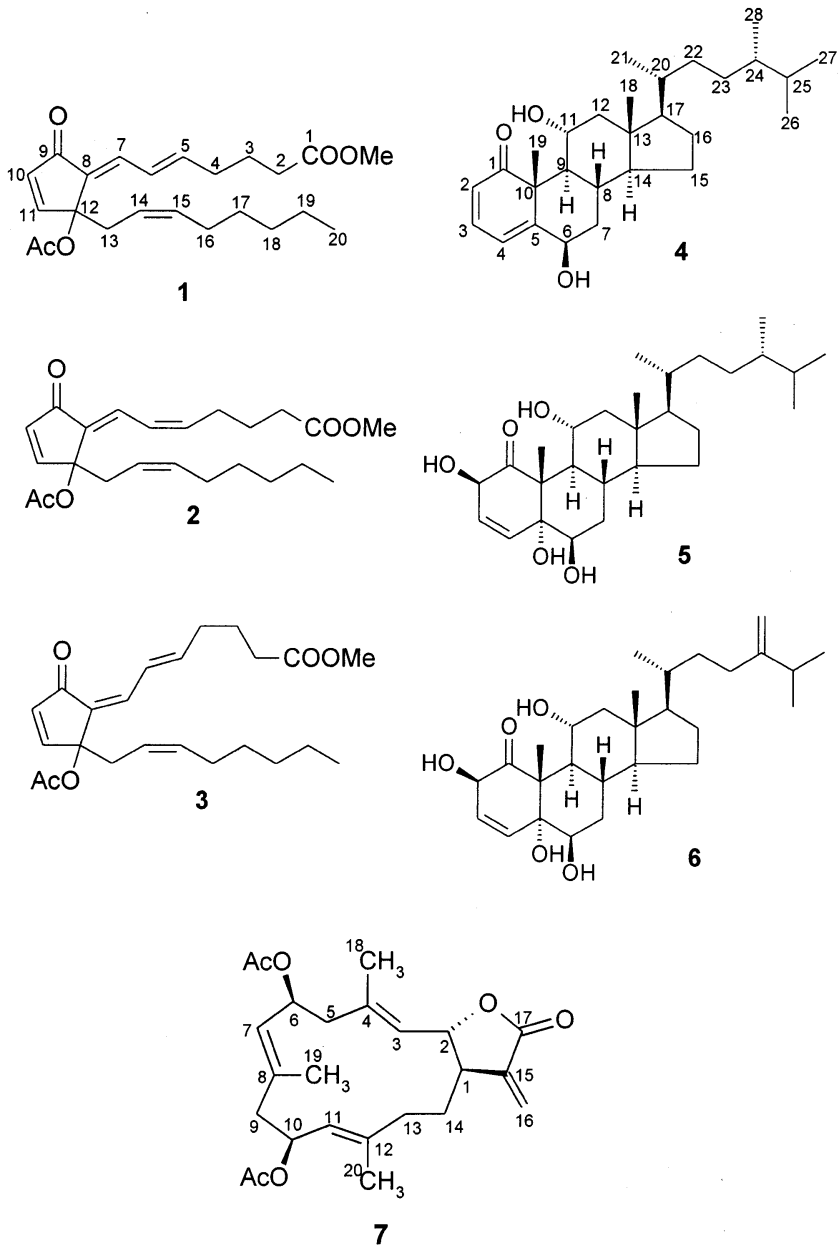

the correlations starting from a doublet at $\delta_{\mathrm{H}} 6.92(1 \mathrm{H}, \mathrm{d}$, $\mathrm{J}=11.7 \mathrm{~Hz}, \mathrm{H}-7)$ and carried through to a triplet at $\delta_{\mathrm{H}}$ $2.35(2 \mathrm{H}, \mathrm{t}, \mathrm{J}=7.5 \mathrm{~Hz}, \mathrm{H}-2)$, indicating the partial structure of $\mathrm{H}-7$ through $\mathrm{H}-2$ on the $\alpha$-side chain shown as a bold line in Figure 1 . The connectivity from $\mathrm{H}-13$ to $\mathrm{H}-20$ on the $\omega$-side chain was indicated by the correlations in the ${ }^{1} \mathrm{H}-{ }^{1} \mathrm{H}$ COSY spectrum starting from two doublets of doublets at $\delta_{\mathrm{H}} 2.70(1 \mathrm{H}, \mathrm{dd}, \mathrm{J}=14.4,8.1 \mathrm{~Hz}, \mathrm{H}-13)$ and $2.96(1 \mathrm{H}, \mathrm{dd}, \mathrm{J}=14.4,7.2 \mathrm{~Hz}, \mathrm{H}-13)$ and ending with the methyl protons at $\delta_{\mathrm{H}} 0.88(3 \mathrm{H}, \mathrm{t}, \mathrm{J}=6.9 \mathrm{~Hz}, \mathrm{H}-20)$. These spectroscopic findings showed $\mathbf{1}$ to have a structure similar to that of clavulone II, ${ }^{4}$ except for $\mathrm{C}-4\left(\mathrm{CH}_{2}\right.$ in 1 ; $\mathrm{CHOAC}$ 
Table 1. ${ }^{1} \mathrm{H}$ and ${ }^{13} \mathrm{C}$ NMR Spectral Data of $\mathbf{1}-\mathbf{3}$ in $\mathrm{CDCl}_{3}$

\begin{tabular}{|c|c|c|c|c|c|c|}
\hline \multirow[b]{2}{*}{ position } & \multicolumn{2}{|r|}{1} & \multicolumn{2}{|r|}{2} & \multicolumn{2}{|r|}{3} \\
\hline & ${ }^{13} \mathrm{Ca}^{\mathrm{a}}$ & ${ }^{1} \mathrm{H}^{\mathrm{b}}$ & ${ }^{13} \mathrm{Ca}^{\mathrm{a}}$ & ${ }^{1} \mathrm{H}^{\mathrm{b}}$ & ${ }^{13} \mathrm{C}^{\mathrm{a}}$ & ${ }^{1} \mathrm{H}^{b}$ \\
\hline 1 & $173.6 \mathrm{~s}$ & & $173.7 \mathrm{~s}$ & & $174.6 \mathrm{~s}$ & \\
\hline 2 & $33.3 \mathrm{t}$ & $2.35(t, 7.5)$ & $33.4 \mathrm{t}$ & $2.34 \mathrm{~m}$ & $33.5 \mathrm{t}$ & $2.36(t, 7.5)$ \\
\hline 3 & $23.9 \mathrm{t}$ & $1.81(t, 8.1)$ & $24.5 \mathrm{t}$ & $1.63(\mathrm{ddd}, 13.5,8.0,7.5)$ & $24.1 \mathrm{t}$ & $1.81(\mathrm{t}, 7.2)$ \\
\hline & $32.7 t$ & $2.33 \mathrm{~m}$ & $27.3 \mathrm{t}$ & $2.36 \mathrm{~m}$ & $32.5 \mathrm{t}$ & $2.29(\mathrm{dd}, 14.1,6.9)$ \\
\hline 5 & $146.5 d$ & $6.22(\mathrm{dt}, 15.0,7.2)$ & $146.5 d$ & $6.04(\mathrm{dt}, 10.8,8.1)$ & $145.6 \mathrm{~d}$ & $6.11(\mathrm{dt}, 15.2,7.2)$ \\
\hline 6 & $125.4 \mathrm{~d}$ & $6.54(\mathrm{dd}, 15.0,11.7)$ & $123.2 \mathrm{~d}$ & $6.54(\mathrm{dd}, 12.3,10.8)$ & $126.7 \mathrm{~d}$ & $7.61(\mathrm{dd}, 15.2,11.4)$ \\
\hline 7 & $131.4 \mathrm{~d}$ & $6.92(d, 11.7)$ & $125.6 \mathrm{~d}$ & $7.25(d, 12.6)$ & $134.7 \mathrm{~d}$ & $6.54(d, 11.4)$ \\
\hline 8 & $134.0 \mathrm{~s}$ & & $135.5 \mathrm{~s}$ & & $133.3 \mathrm{~s}$ & \\
\hline 9 & $193.9 \mathrm{~s}$ & & $194.0 \mathrm{~s}$ & & $194.4 \mathrm{~s}$ & \\
\hline 10 & $134.8 d$ & $6.41(d, 6.0)$ & $135.3 d$ & $6.43(d, 6.0)$ & $136.9 \mathrm{~d}$ & $6.36(d, 6.3)$ \\
\hline 11 & $\begin{array}{r}157.5 \mathrm{~d} \\
85.6 \mathrm{~s}\end{array}$ & $7.48(\mathrm{~d}, 6.0)$ & $\begin{array}{r}157.8 \mathrm{~d} \\
85.5 \mathrm{~s}\end{array}$ & $7.48(d, 6.0)$ & $\begin{array}{r}155.8 \mathrm{~d} \\
85.7 \mathrm{~s}\end{array}$ & $7.51(d, 6.3)$ \\
\hline 13 & $35.7 \mathrm{t}$ & $\begin{array}{l}2.96(\mathrm{dd}, 14.4,7.2) \\
2.70(\mathrm{dd}, 14.4,8.1)\end{array}$ & $35.6 \mathrm{t}$ & $\begin{array}{l}2.97(\mathrm{dd}, 14.0,6.6) \\
2.70(\mathrm{dd}, 14.0,8.4)\end{array}$ & $35.6 \mathrm{t}$ & $\begin{array}{l}2.88(d d, 14.5,7.5) \\
2.65(d d, 14.5,7.5)\end{array}$ \\
\hline 14 & $121.3 d$ & $5.17 \mathrm{~m}$ & $121.3 \mathrm{~d}$ & $5.17 \mathrm{~m}$ & $120.6 d$ & $5.23 \mathrm{~m}$ \\
\hline 15 & $135.3 d$ & $5.50 \mathrm{~m}$ & $134.9 \mathrm{~d}$ & $5.51 \mathrm{~m}$ & $135.4 \mathrm{~d}$ & $5.53 \mathrm{~m}$ \\
\hline 16 & $27.5 \mathrm{t}$ & $1.97(\mathrm{dd}, 6.9,5.1)$ & $27.5 \mathrm{t}$ & $1.95 \mathrm{~m}$ & $27.5 \mathrm{t}$ & $1.95 \mathrm{~m}$ \\
\hline 17 & $29.1 \mathrm{t}$ & $1.29 \mathrm{~m}$ & $29.7 t$ & $1.28 \mathrm{~m}$ & $29.1 \mathrm{t}$ & $1.29 \mathrm{~m}$ \\
\hline 18 & $31.6 \mathrm{t}$ & $1.30 \mathrm{~m}$ & $31.6 \mathrm{t}$ & $1.26 \mathrm{~m}$ & $31.6 \mathrm{t}$ & $1.27 \mathrm{~m}$ \\
\hline 19 & $22.6 \mathrm{t}$ & $1.32 \mathrm{~m}$ & $22.6 \mathrm{t}$ & $1.31 \mathrm{~m}$ & $22.6 \mathrm{t}$ & $1.31 \mathrm{~m}$ \\
\hline 20 & $14.1 \mathrm{q}$ & $0.88(t, 6.9)$ & $14.1 \mathrm{q}$ & $0.88(t, 6.9)$ & $14.1 \mathrm{q}$ & $0.88(t, 6.6)$ \\
\hline $\mathrm{OCH}_{3}$ & $51.6 \mathrm{q}$ & $3.68 \mathrm{~s}$ & $51.7 \mathrm{q}$ & $3.69 \mathrm{~s}$ & $51.6 \mathrm{q}$ & $3.68 \mathrm{~s}$ \\
\hline $\mathrm{CH}_{3} \mathrm{CO}$ & $169.4 \mathrm{~s}$ & & $169.4 \mathrm{~s}$ & & $169.8 \mathrm{~s}$ & \\
\hline $\mathrm{CH}_{3} \mathrm{CO}$ & $21.4 \mathrm{q}$ & $2.04 \mathrm{~s}$ & $21.4 \mathrm{q}$ & $2.04 \mathrm{~s}$ & $21.4 \mathrm{q}$ & $1.99 \mathrm{~s}$ \\
\hline
\end{tabular}

a Multiplicities of resonances were deduced by DEPT experiments. ${ }^{b}$ Multiplicities and J $(\mathrm{Hz})$ values are presented in parentheses.

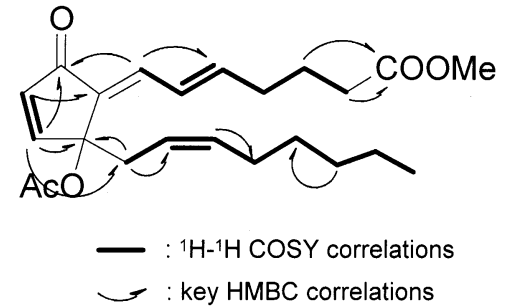

Figure 1. ${ }^{1} \mathrm{H}-{ }^{1} \mathrm{H}$ COSY and key $\mathrm{HMBC}$ correlations of $\mathbf{1}$.

in clavulone II ) on the $\alpha$-side chain. Assignments between the ${ }^{1 \mathrm{H}}$ and ${ }^{13} \mathrm{C}$ NMR signals were made on the basis of HSQC correlations. The data from the HMBC spectrum fully supported the assigned structure, and key HMBC correlations are shown in Figure 1.

The molecular formula of compound $\mathbf{2}$ was assigned as $\mathrm{C}_{23} \mathrm{H}_{32} \mathrm{O}_{5}$ by HREIMS and NMR data. The ${ }^{1} \mathrm{H}$ and ${ }^{13} \mathrm{C}$ NMR spectra of $\mathbf{2}$ were very similar to those of $\mathbf{1}$ except for the ${ }^{1} \mathrm{H}$ coupling constant between the two ol efinic protons at $\mathrm{H}-5$ and $\mathrm{H}-6(10.8 \mathrm{~Hz}$ in $2 ; 15.0 \mathrm{~Hz}$ in 1$)$ and the ${ }^{13} \mathrm{C}$ chemical shifts at C-4 $\left(\delta_{\mathrm{C}} 27.3\right.$ in 2; 32.7 in $\left.\mathbf{1}\right)$ and C-7 $\left(\delta_{\mathrm{C}}\right.$ 125.6 in 2; 131.4 in 1). Compound $\mathbf{2}$ was thus assigned as a $5 \mathrm{Z}$ isomer of $\mathbf{1}$ on the basis of the comparison of ${ }^{1} \mathrm{H}$ and ${ }^{13} \mathrm{C}$ NMR data with those of clavul one II. ${ }^{4}$ NOESY correlations from $\mathrm{H}-5$ to $\mathrm{H}-6$ and from $\mathrm{H}-4$ to $\mathrm{H}-7$ confirmed this assignment. The assignments of the ${ }^{1} \mathrm{H}$ and ${ }^{13} \mathrm{C} N \mathrm{NR}$ signals were accomplished by COSY, HSQC, HMBC, and NOESY experiments.

The molecular formula of compound $\mathbf{3}$ was shown to be $\mathrm{C}_{23} \mathrm{H}_{32} \mathrm{O}_{5}$ by HREIMS and NMR data. The ${ }^{1} \mathrm{H}$ and ${ }^{13} \mathrm{C}$ NMR spectra of $\mathbf{3}$ were also very similar to those of $\mathbf{1}$ except for the ${ }^{1} \mathrm{H}$ chemical shift values at $\mathrm{H}-6\left(\delta_{\mathrm{H}} 7.61\right.$ in 3; 6.54 in 1) and $\mathrm{H}-7\left(\delta_{\mathrm{H}} 6.54\right.$ in 3; 6.92 in $\left.\mathbf{1}\right)$ and the ${ }^{13} \mathrm{C}$ chemical shifts at C-7 ( $\delta_{\mathrm{C}} 134.7$ in 3; 131.4 in 1). Compound $\mathbf{3}$ was thus assigned as a $7 Z$ isomer of $\mathbf{1}$ on the basis of the comparison of ${ }^{1 \mathrm{H}}$ and ${ }^{13} \mathrm{C}$ NMR data with those of clavulone II. ${ }^{4}$ The assignments of the ${ }^{1} \mathrm{H}$ and ${ }^{13} \mathrm{C}$ NMR signals were confirmed by COSY, HSQC, HMBC, and NOESY experiments.

Compound 4 had a molecular formula of $\mathrm{C}_{28} \mathrm{H}_{44} \mathrm{O}_{3}$ as indicated by HREIMS. ${ }^{13} \mathrm{C}$ NMR and DEPT spectra of $\mathbf{4}$ exhibited the presence of six methyls, six $\mathrm{sp}^{3}$ methylenes, nine $\mathrm{sp}^{3}$ methines, three $\mathrm{sp}^{2}$ methines, two $\mathrm{sp}^{3}$ quaternary carbons, and two $\mathrm{sp}^{2}$ quaternary carbons. The IR spectrum of $\mathbf{4}$ showed absorption due to an $\alpha, \beta$-unsaturated ketone $\left(1676 \mathrm{~cm}^{-1}\right)$. The presence of a conjugated enone system in $\mathbf{4}$ was also indicated by UV absorptions at $222 \mathrm{~nm}$ (log $\epsilon 3.79)$ and $280(\log \epsilon 4.01) \mathrm{nm}$ as well as ${ }^{1} \mathrm{H}$ NMR $[\delta 6.18$ $(1 \mathrm{H}, \mathrm{d}, \mathrm{J}=9.6 \mathrm{~Hz}), 6.19(1 \mathrm{H}, \mathrm{d}, \mathrm{J}=6.0 \mathrm{~Hz}), 6.99(1 \mathrm{H}, \mathrm{dd}$, $\mathrm{J}=9.6,6.0 \mathrm{~Hz})]$ and ${ }^{13} \mathrm{C}$ NMR $[\delta 118.9(\mathrm{CH}), 126.7(\mathrm{CH})$, $140.8(\mathrm{CH}), 157.8(\mathrm{C})]$ spectra (Table 2). IR absorption at $3300 \mathrm{~cm}^{-1}$ and NMR signals at $\delta_{\mathrm{H}} 4.58(1 \mathrm{H}, \mathrm{br} \mathrm{s})$ and 4.04 $(1 \mathrm{H}, \mathrm{dt}, \mathrm{J}=3.7,10.5 \mathrm{~Hz})$ as well as at $\delta_{\mathrm{C}} 73.6(\mathrm{CH})$ and $66.9(\mathrm{CH})$ indicated the presence of two secondary hydroxyl groups. The spectral data of $\mathbf{4}$ exhibited some similarity to those of yonarasterol $E,{ }^{5}$ except for the presence of a trisubstituted double bond and lacking the epoxide. All $\mathrm{C}-\mathrm{H}$ correlations of $\mathbf{4}$ were detected in the HSQC experiment. The ${ }^{1} \mathrm{H}-{ }^{1} \mathrm{H}$ COSY spectrum exhibited partial structures $\mathbf{a}, \mathbf{b}$, and $\mathbf{c}$ (Figure 2). In the HMBC spectrum, partial structure $\mathbf{a}$ could be connected to $\mathbf{b}$ through two quaternary carbons (C-5 and C-10) and $\mathrm{H}_{3}-19$ (Figure 2). Partial structure $\mathbf{b}$ could be connected to $\mathbf{c}$ through the remaining quaternary carbons ( $\mathrm{C}-13)$ and $\mathrm{H}_{3}-18$. On the basis of these findings, the gross structure of $\mathbf{4}$ was concluded as in Figure 2. The NOESY correlations (Figure 3) observed between $\mathrm{H}-11$ and $\mathrm{H}-8, \mathrm{H}-11$ and $\mathrm{H}_{3}-18, \mathrm{H}-11$ and $\mathrm{H}_{3}-19$, $\mathrm{H}-4$ and $\mathrm{H}-6, \mathrm{H}-9$ and $\mathrm{H}-14, \mathrm{H}_{3}-18$ and $\mathrm{H}-8, \mathrm{H}_{3}-19$ and $\mathrm{H}-8$, $\mathrm{H}_{3}-18$ and $\mathrm{H}-20, \mathrm{H}_{3}-21$ and $\mathrm{H}-12 \beta$, and $\mathrm{H}-9$ and $\mathrm{H}-12 \alpha$ indicated the relative configurations for each ring junction and chiral center. Stereochemistry at C-20 and C-24 was determined by comparison of ${ }^{13} \mathrm{C}$ NMR data with those of yonarasterol $E$ and stoniferone-c. ${ }^{5,6}$

HREIMS and ${ }^{13} \mathrm{C}$ NMR data revealed 5 to have a molecular formula of $\mathrm{C}_{28} \mathrm{H}_{46} \mathrm{O}_{5} .{ }^{13} \mathrm{C}$ and ${ }^{1} \mathrm{H}$ NMR data (Table 2) showed some similarity to $\mathbf{4}$, except for the presence of two additional hydroxyls and the absence of the trisubstituted double bond. The location of the hydroxyls on $\mathrm{C}-2$ and $\mathrm{C}-4$ was made on the basis of ${ }^{1} \mathrm{H}-{ }^{1} \mathrm{H}$ COSY correlations from $\mathrm{H}-2$ to $\mathrm{H}-3$ and $\mathrm{H}-3$ to $\mathrm{H}-4$ and $\mathrm{HMBC}$ correlations (Figure 2) from $\mathrm{H}-2$ to $\mathrm{C}-1, \mathrm{C}-3, \mathrm{C}-4$; $\mathrm{H}-3$ to $\mathrm{C}-1, \mathrm{C}-2, \mathrm{C}-4, \mathrm{C}-5$; and $\mathrm{H}-19$ to $\mathrm{C}-1, \mathrm{C}-5, \mathrm{C}-9, \mathrm{C}-10$. 
Table 2. ${ }^{1} \mathrm{H}$ and ${ }^{13} \mathrm{C}$ NMR Spectral Data of 4-6 in $\mathrm{CDCl}_{3}$

\begin{tabular}{|c|c|c|c|c|c|c|c|c|c|}
\hline \multirow[b]{2}{*}{ position } & \multicolumn{3}{|c|}{4} & \multicolumn{3}{|c|}{5} & \multicolumn{3}{|c|}{6} \\
\hline & ${ }^{13} \mathrm{C}^{\mathrm{a}}$ & & ${ }^{1} \mathrm{H}^{\mathrm{b}}$ & ${ }^{13} \mathrm{C}^{\mathrm{a}}$ & & ${ }^{1} H^{b}$ & ${ }^{13} \mathrm{C}^{\mathrm{a}}$ & & ${ }^{1} \mathrm{H}^{\mathrm{b}}$ \\
\hline 1 & 212.4 & (C) & & 212.5 & (C) & & 212.8 & (C) & \\
\hline 2 & 126.7 & $(\mathrm{CH})$ & $6.18(d, 9.6)$ & 78.6 & $(\mathrm{CH})$ & 7.02 (dd, 8.1, 1.2) & 78.5 & $(\mathrm{CH})$ & 7.01 (dd, 8.0, 1.5) \\
\hline 3 & 140.8 & $(\mathrm{CH})$ & $6.99(\mathrm{dd}, 9.6,6.0)$ & 126.5 & $(\mathrm{CH})$ & $6.70(\mathrm{dd}, 8.1,6.3)$ & 126.4 & $(\mathrm{CH})$ & $6.70(\mathrm{dd}, 8.0,6.5)$ \\
\hline 4 & 118.9 & $(\mathrm{CH})$ & $6.19(d, 6.0)$ & 141.8 & $(\mathrm{CH})$ & $4.63(\mathrm{dd}, 6.3,1.2)$ & 141.7 & $(\mathrm{CH})$ & $4.62(\mathrm{dd}, 6.5,1.5)$ \\
\hline 5 & 157.8 & (C) & & 84.0 & (C) & & 83.9 & (C) & \\
\hline 6 & 73.6 & $(\mathrm{CH})$ & $4.58 \mathrm{br} \mathrm{s}$ & 67.0 & $(\mathrm{CH})$ & $4.08 \mathrm{~m}$ & 66.9 & $(\mathrm{CH})$ & $4.07 \mathrm{~m}$ \\
\hline 7 & 40.3 & $\left(\mathrm{CH}_{2}\right)$ & $\begin{array}{l}1.28 \mathrm{~m} \\
2.01 \mathrm{~m}\end{array}$ & 34.9 & $\left(\mathrm{CH}_{2}\right)$ & $1.69 \mathrm{~m}$ & 34.8 & $\left(\mathrm{CH}_{2}\right)$ & \\
\hline 8 & 29.7 & $(\mathrm{CH})$ & $2.08 \mathrm{~m}$ & 27.8 & $(\mathrm{CH})$ & $1.85 \mathrm{~m}$ & 27.7 & $(\mathrm{CH})$ & \\
\hline 9 & 58.1 & $(\mathrm{CH})$ & $1.40 \mathrm{~m}$ & 50.1 & $(\mathrm{CH})$ & $2.00(t, 9.9)$ & 49.9 & $(\mathrm{CH})$ & $2.00(t, 10.5)$ \\
\hline 10 & 55.4 & (C) & & 49.3 & (C) & & 49.2 & (C) & \\
\hline 11 & 66.9 & $(\mathrm{CH})$ & $4.04 \mathrm{~m}$ & 67.1 & $(\mathrm{CH})$ & $4.10 \mathrm{~m}$ & 67.0 & $(\mathrm{CH})$ & $4.10 \mathrm{~m}$ \\
\hline 12 & 49.5 & $\left(\mathrm{CH}_{2}\right)$ & $\begin{array}{l}2.39(\mathrm{dd}, 9.6,6.0) \\
1.23 \mathrm{~m}\end{array}$ & 48.6 & $\left(\mathrm{CH}_{2}\right)$ & $\begin{array}{l}2.37(\mathrm{dd}, 12.6,4.8) \\
1.31 \mathrm{~m}\end{array}$ & 48.5 & $\left(\mathrm{CH}_{2}\right)$ & $\begin{array}{l}2.37(\mathrm{dd}, 12.0,4.5) \\
1.30 \mathrm{~m}\end{array}$ \\
\hline 13 & 42.8 & (C) & & 42.8 & (C) & & 42.7 & (C) & \\
\hline 14 & 54.8 & $(\mathrm{CH})$ & $1.12 \mathrm{~m}$ & 54.4 & $(\mathrm{CH})$ & $1.29 \mathrm{~m}$ & 54.3 & $(\mathrm{CH})$ & \\
\hline 15 & 24.5 & $\left(\mathrm{CH}_{2}\right)$ & $\begin{array}{l}1.13 \mathrm{~m} \\
1.57 \mathrm{~m}\end{array}$ & 24.4 & $\left(\mathrm{CH}_{2}\right)$ & $\begin{array}{l}1.12 \mathrm{~m} \\
1.63 \mathrm{~m}\end{array}$ & 24.3 & $\left(\mathrm{CH}_{2}\right)$ & \\
\hline 16 & 28.2 & $\left(\mathrm{CH}_{2}\right)$ & $\begin{array}{l}1.28 \mathrm{~m} \\
1.87 \mathrm{~m}\end{array}$ & 28.2 & $\left(\mathrm{CH}_{2}\right)$ & $\begin{array}{l}1.32 \mathrm{~m} \\
1.88 \mathrm{~m}\end{array}$ & 28.1 & $\left(\mathrm{CH}_{2}\right)$ & \\
\hline 17 & 55.9 & $(\mathrm{CH})$ & $1.13 \mathrm{~m}$ & 56.1 & $(\mathrm{CH})$ & $1.24 \mathrm{~m}$ & 56.0 & $(\mathrm{CH})$ & \\
\hline 18 & 13.0 & $\left(\mathrm{CH}_{3}\right)$ & $0.79 \mathrm{~s}$ & 13.2 & $\left(\mathrm{CH}_{3}\right)$ & $0.75 \mathrm{~s}$ & 13.1 & $\left(\mathrm{CH}_{3}\right)$ & $0.75 \mathrm{~s}$ \\
\hline 19 & 18.7 & $\left(\mathrm{CH}_{3}\right)$ & $1.71 \mathrm{~s}$ & 20.2 & $\left(\mathrm{CH}_{3}\right)$ & $1.42 \mathrm{~s}$ & 20.1 & $\left(\mathrm{CH}_{3}\right)$ & $1.41 \mathrm{~s}$ \\
\hline 20 & 36.1 & $(\mathrm{CH})$ & $1.38 \mathrm{~m}$ & 36.3 & $(\mathrm{CH})$ & $1.37 \mathrm{~m}$ & 35.7 & $(\mathrm{CH})$ & \\
\hline 21 & 19.9 & $\left(\mathrm{CH}_{3}\right)$ & $0.96(d, 6.3)$ & 18.8 & $\left(\mathrm{CH}_{3}\right)$ & $0.97(d, 6.6)$ & 18.5 & $\left(\mathrm{CH}_{3}\right)$ & $0.98(d, 6.6)$ \\
\hline 22 & 33.5 & $\left(\mathrm{CH}_{2}\right)$ & $\begin{array}{l}0.95 \mathrm{~m} \\
1.40 \mathrm{~m}\end{array}$ & 33.6 & $\left(\mathrm{CH}_{2}\right)$ & $\begin{array}{l}0.96 \mathrm{~m} \\
1.40 \mathrm{~m}\end{array}$ & 34.5 & $\left(\mathrm{CH}_{2}\right)$ & \\
\hline 23 & 30.6 & $\left(\mathrm{CH}_{2}\right)$ & $1.39 \mathrm{~m}$ & 30.7 & $\left(\mathrm{CH}_{2}\right)$ & $\begin{array}{l}0.97 \mathrm{~m} \\
1.38 \mathrm{~m}\end{array}$ & 31.0 & $\left(\mathrm{CH}_{2}\right)$ & \\
\hline 24 & 39.0 & $(\mathrm{CH})$ & $1.20 \mathrm{~m}$ & 39.1 & $(\mathrm{CH})$ & $1.22 \mathrm{~m}$ & 156.6 & (C) & \\
\hline 25 & 31.4 & $(\mathrm{CH})$ & $1.55 \mathrm{~m}$ & 32.0 & $(\mathrm{CH})$ & $1.57 \mathrm{~m}$ & 33.8 & $(\mathrm{CH})$ & \\
\hline 26 & 20.5 & $\left(\mathrm{CH}_{3}\right)$ & $0.86(d, 6.6)$ & 20.6 & $\left(\mathrm{CH}_{3}\right)$ & $0.86(d, 6.9)$ & 22.1 & $\left(\mathrm{CH}_{3}\right)$ & $1.03(d, 6.5)$ \\
\hline 27 & 17.6 & $\left(\mathrm{CH}_{3}\right)$ & $0.78(d, 6.6)$ & 17.7 & $\left(\mathrm{CH}_{3}\right)$ & $0.79(d, 6.7)$ & 22.0 & $\left(\mathrm{CH}_{3}\right)$ & $1.04(d, 6.5)$ \\
\hline 28 & 15.4 & $\left(\mathrm{CH}_{3}\right)$ & $0.79(\mathrm{~d}, 6.3)$ & 15.5 & $\left(\mathrm{CH}_{3}\right)$ & $0.80(d, 6.7)$ & 106.0 & $\left(\mathrm{CH}_{2}\right)$ & $\begin{array}{l}4.66 \text { br s } \\
4.72 \text { br s }\end{array}$ \\
\hline
\end{tabular}

a Multiplicities of resonances were deduced by DEPT experiments. ${ }^{b}$ Multiplicities and J ( $\left.\mathrm{Hz}\right)$ values are presented in parentheses.

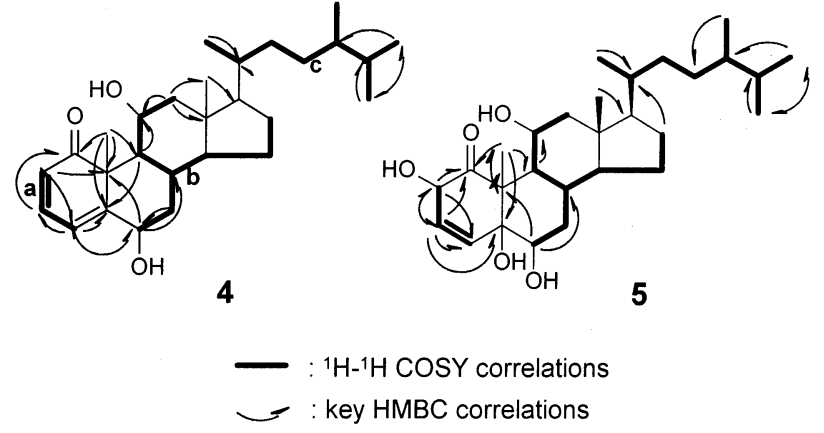

Figure 2. ${ }^{1} \mathrm{H}-{ }^{1} \mathrm{H}$ COSY and key $\mathrm{HMBC}$ correlations of $\mathbf{4}$ and $\mathbf{5}$.

The NOESY correlations (Figure 3 ) observed between $\mathrm{H}-4$ and $\mathrm{H}_{3}-19, \mathrm{H}-4$ and $\mathrm{H}-6, \mathrm{H}-11$ and $\mathrm{H}-8, \mathrm{H}-11$ and $\mathrm{H}_{3}-18$, $\mathrm{H}-11$ and $\mathrm{H}_{3}-19, \mathrm{H}-9$ and $\mathrm{H}-14, \mathrm{H}_{3}-18$ and $\mathrm{H}-8, \mathrm{H}_{3}-19$ and $\mathrm{H}-8, \mathrm{H}_{3}-18$ and $\mathrm{H}-20, \mathrm{H}_{3}-21$ and $\mathrm{H}-12 \beta$, and $\mathrm{H}-9$ and $\mathrm{H}-12 \alpha$ indicated the relative configurations for each ring junction and chiral center.

The molecular formula of compound $\mathbf{6}$ was assigned as $\mathrm{C}_{28} \mathrm{H}_{44} \mathrm{O}_{5}$ by $\mathrm{HREI} M S$ and NMR data. The ${ }^{1} \mathrm{H}$ and ${ }^{13} \mathrm{C} \mathrm{NMR}$ spectra of $\mathbf{6}$ were very similar to those of $\mathbf{5}$ except for NMR signals due to the side chain. Stereochemistry at C-20 was determined by comparison of ${ }^{13} \mathrm{C}$ NMR data with those of stoniferone-a. ${ }^{6}$

Compound 7 was isolated as a colorless oil, $[\alpha]^{25} \mathrm{D}-33.8^{\circ}$ (c $0.05, \mathrm{CHCl}_{3}$ ). HREIMS, ${ }^{13} \mathrm{C} \mathrm{NMR}$, and DEPT spectra established the molecular formula of 7 as $\mathrm{C}_{24} \mathrm{H}_{32} \mathrm{O}_{6}$. The IR spectrum of $\mathbf{7}$ indicated the presence of the functionalities of ester group(s) $\left(v_{\max } 1730,1240 \mathrm{~cm}^{-1}\right)$ and $\alpha$-methylene $\gamma$-lactone $\left(v_{\max } 1760,1660 \mathrm{~cm}^{-1}\right)$. The presence of the
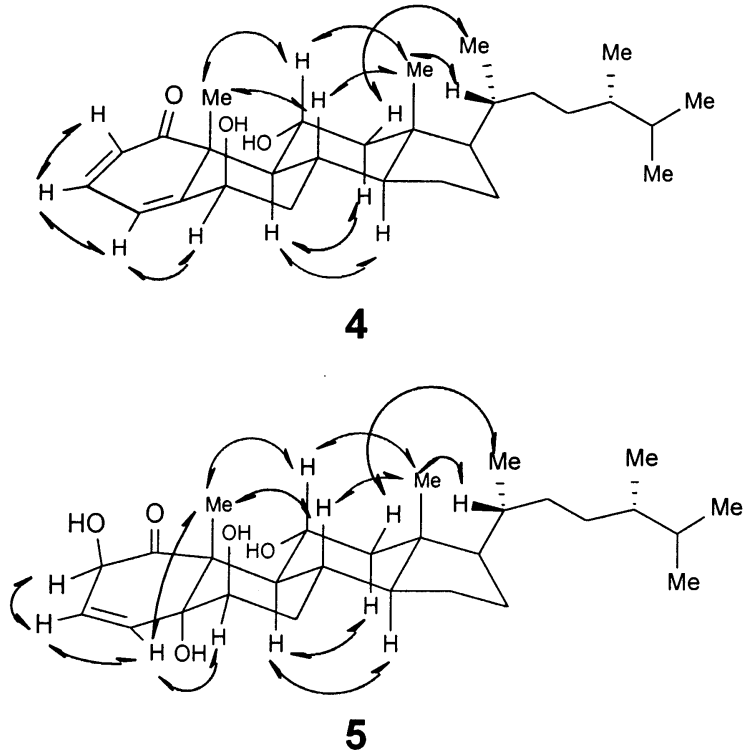

Figure 3. Selective NOESY correlations of $\mathbf{4}$ and $\mathbf{5}$.

$\alpha$-methylene- $\gamma$-lactone system in $\mathbf{7}$ was also demonstrated by UV absorption at $210(\log \epsilon 4.12) \mathrm{nm}$ and signals at $\delta$ $5.57\left(\mathrm{H}-16_{\mathrm{a}}\right)$ and $6.27\left(\mathrm{H}-16_{\mathrm{b}}\right)$ in the ${ }^{1} \mathrm{H}$ NMR spectrum. The ${ }^{1} \mathrm{H}$ NMR spectrum of $\mathbf{7}$ also showed signals for three ol efinic protons at $\delta 5.02(\mathrm{H}-3), 5.09(\mathrm{H}-11)$, and $5.15(\mathrm{H}-7)$ ppm; three oxymethine protons either bearing three acetates or in the $\gamma$-lactone group at $\delta 4.84(\mathrm{H}-2), 5.57(\mathrm{H}-6)$, and $5.71(\mathrm{H}-10)$; three olefinic methyl groups at $\delta 1.69\left(\mathrm{H}_{3^{-}}\right.$ 19), $1.73\left(\mathrm{H}_{3}-20\right)$, and $1.83\left(\mathrm{H}_{3}-18\right)$; and two methyl groups 


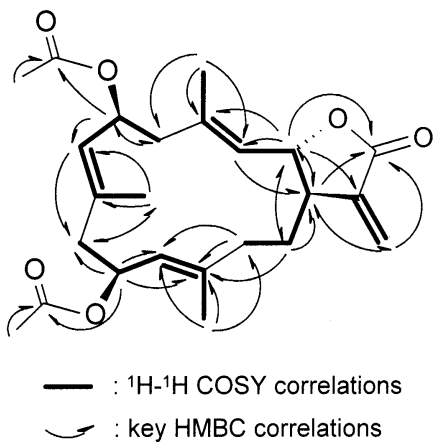

Figure 4. ${ }^{1} \mathrm{H}-{ }^{1} \mathrm{H}$ COSY and key $\mathrm{HMBC}$ correlations of 7.

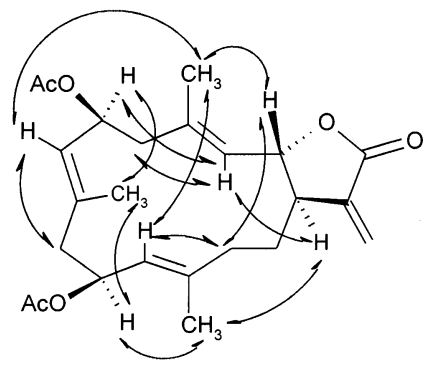

Figure 5. Selective NOESY correlations of $\mathbf{7}$.

Table 3. Cytotoxicitya of 1-7

\begin{tabular}{clll}
\hline & \multicolumn{3}{c}{ cell lines ED $\mathrm{E}_{50}(\mu \mathrm{g} / \mathrm{mL})$} \\
\cline { 2 - 4 } compound & \multicolumn{1}{c}{ A549 } & \multicolumn{1}{c}{ HT-29 } & \multicolumn{1}{c}{ P-388 } \\
\hline $\mathbf{1}$ & $4.1 \times 10^{-1}$ & 1.02 & $1.1 \times 10^{-1}$ \\
$\mathbf{2}$ & $5.0 \times 10^{-3}$ & $5.1 \times 10^{-2}$ & $5.2 \times 10^{-7}$ \\
$\mathbf{3}$ & $5.1 \times 10^{-2}$ & 1.22 & $2.6 \times 10^{-1}$ \\
$\mathbf{4}$ & $3.2 \times 10^{-4}$ & $9.1 \times 10^{-3}$ & $1.2 \times 10^{-4}$ \\
$\mathbf{5}$ & 3.69 & 6.46 & 2.36 \\
$\mathbf{6}$ & 3.58 & 5.86 & 2.12 \\
$\mathbf{7}$ & 4.91 & $8.4 \times 10^{-1}$ & $3.8 \times 10^{-1}$
\end{tabular}

a For significant activity of pure compounds, an $E D_{50}$ of $\leq 4.0$ $\mu \mathrm{g} / \mathrm{mL}$ is required.

in acetate esters at $\delta 2.01$ and 2.03. The ${ }^{1} \mathrm{H}-{ }^{1} \mathrm{H}$ COSY spectrum exhibited correlations from $\mathrm{H}-13$ to $\mathrm{H}-3, \mathrm{H}-5$ to $\mathrm{H}-6$, and $\mathrm{H}-9$ to $\mathrm{H}-11{ }^{1} \mathrm{H}-{ }^{1} \mathrm{H}$ long-range correlations were also observed from $\mathrm{H}-1$ to $\mathrm{H}_{2}-16, \mathrm{H}-3$ to $\mathrm{H}_{3}-18, \mathrm{H}-7$ to $\mathrm{H}_{3}$ 19, and $\mathrm{H}-11$ to $\mathrm{H}_{3}-20$. These spectroscopic findings and the nine degrees of unsaturations indicated that 7 was a 14-membered cembrane-type diterpene skeleton with an $\alpha$-methylene- $\gamma$-lactone. After assignments between all the $\mathrm{C}-\mathrm{H}$ bondings were made on the basis of HSQC experiment, the planar structure was determined by HMBC analysis. The correlations according to HMBC are shown in Figure 4. The stereochemistry for the three trisubstituted ol efins of $\mathbf{7}$ was determined by NOESY analysis. The NOESY correlations between $\mathrm{H}-3$ and $\mathrm{H}-5, \mathrm{H}-7$ and $\mathrm{H}-9$, and $\mathrm{H}-11$ and $\mathrm{H}-13$ disclosed the all-E configurations for the three trisubstituted olefins. The chemical shift values at $\delta_{\mathrm{C}}$ 19.9, 16.3, and 15.5 (for C-18, C-19, and C-20, respectively) also supported the all-E configurations. ${ }^{7}$ The relative configurations at $\mathrm{C}-1$ and $\mathrm{C}-2$ were determined by the coupling constant observed for the $\mathrm{H}-1$ and $\mathrm{H}-2$ proton signals and NOESY correlations (Figure 5) between $\mathrm{H}-1$ and $\mathrm{H}-3$ and $\mathrm{H}-2$ and $\mathrm{H}-13$. The relative configurations of the remaining two chiral centers at C- 6 and C-10 were deduced from the following NOE analysis. NOESY correlations (Figure 5) between $\mathrm{H}-2$ and $\mathrm{H}-18, \mathrm{H}-18$ and $\mathrm{H}-7$, and $\mathrm{H}-18$ and $\mathrm{H}-11$ indicated that these protons $(\mathrm{H}-2, \mathrm{H}-7$, $\mathrm{H}-11$, and $\mathrm{H}-18$ ) were oriented on the same side, while NOESY correlations between $\mathrm{H}-1$ and $\mathrm{H}-3$ and $\mathrm{H}-1$ and $\mathrm{H}-20$ demonstrated that these protons $(\mathrm{H}-1, \mathrm{H}-3$, and $\mathrm{H}-20)$ were oriented on the opposite face of the molecule. According to the relationships of these protons, the relative configurations at C- 6 and C-10 were determined by NOESY correlations (Figure 5) between $\mathrm{H}-6$ and $\mathrm{H}-3, \mathrm{H}-6$ and $\mathrm{H}-19$, $\mathrm{H}-19$ and $\mathrm{H}-10$, and $\mathrm{H}-10$ and $\mathrm{H}-20$.

The cytotoxicity of compounds $\mathbf{1 - 7}$ is shown in Table 3. Compounds $\mathbf{2}$ and $\mathbf{4}$ exhibited potent cytotoxicity against P-388, HT-29, and A549 cells. Compound 3 showed exceptionally potent cytotoxicty against A549 cells.

\section{Experimental Section}

General Experimental Procedures. Optical rotations were determined on a J ASCO DIP-181 polarimeter. UV spectra were obtained on a Shimadzu UV-160A spectrophotometer, and IR spectra were recorded on a Hitachi 26-30 spectrophotometer. The NMR spectra were recor ded on a Bruker Avance $300 \mathrm{NMR}$ spectrometer at $300 \mathrm{MHz}$ for ${ }^{1} \mathrm{H}$ and $75 \mathrm{MHz}$ for ${ }^{13} \mathrm{C}$, respectively, in $\mathrm{CDCl}_{3}$ using TMS as internal standard. EIMS spectra were obtained with a J EOL J MS-SX/SX 102A mass spectrometer at $70 \mathrm{eV}$. Si gel 60 (Merck, 230-400 mesh) was used for col umn chromatography; precoated Si gel plates (Merck, Kieselgel $60 \mathrm{~F}_{254}, 0.25 \mathrm{~mm}$ ) were used for TLC analysis.

Animal Material. The soft coral C. viridis was collected at Green Island, off Taiwan, in May 2001, at a depth of 1-2 $\mathrm{m}$ and was stored for 1 month in a freezer until extraction. A voucher specimen, NSUGN-052, was deposited in the Department of Marine Resources, National Sun Yat-sen University, Taiwan.

The soft coral C. violacea was collected at Green I sland, off Taiwan, in October 2000, at a depth of 5-6 $\mathrm{m}$ and was stored for 1 week in a freezer until extraction. A voucher specimen, NSUGN-033, was deposited in the Department of Marine Resources, National Sun Yat-sen University, Taiwan.

Extraction and Isolation. The bodies of the soft coral C. viridis were freeze-dried to give $1.60 \mathrm{~kg}$ of a solid, which was extracted with $\mathrm{CH}_{2} \mathrm{Cl}_{2}(4.0 \mathrm{~L} \times 3)$. After removal of solvent in vacuo, the residue $(70 \mathrm{~g}$ ) was chromatographed over Si gel 60 using n-hexane and n-hexane-EtOAc mixtures of increasing polarity. Elution by $n$-hexane-EtOAc (8:2) afforded fractions containing compounds $\mathbf{1}-\mathbf{3}$. Elution by $n$-hexane-EtOAc (6: 4) afforded fractions containing compounds 4-6. Compounds 1-3 were further purified by Si gel column chromatography, by eluting with n-hexane-acetone (11:1). Compounds 4-6 were further purified by Si gel column chromatography by eluting with $\mathrm{CH}_{2} \mathrm{Cl}_{2}-\mathrm{EtOAc}$ (7:3) and $\mathrm{C}_{18} \mathrm{HPLC}$ column by using $\mathrm{MeOH}-\mathrm{H}_{2} \mathrm{O}(85: 15)$ as solvent system.

The bodies of the soft coral $\mathrm{C}$. violacea were freeze-dried to give $240 \mathrm{~g}$ of a solid, which was extracted with $\mathrm{CH}_{2} \mathrm{Cl}_{2}(2.0 \mathrm{~L}$ $\times 3)$. After removal of solvent in vacuo, the residue $(20 \mathrm{~g})$ was chromatographed over Si gel 60 using $\mathrm{CH}_{2} \mathrm{Cl}_{2}$ and $\mathrm{CH}_{2} \mathrm{Cl}_{2}-$ acetone mixtures of increasing polarity. Elution by $\mathrm{CH}_{2} \mathrm{Cl}_{2}$ afforded a fraction containing compound 7. Compound $\mathbf{7}$ were further purified by Si gel column chromatography by eluting with n-hexane-EtOAc (1:1).

Claviridenone E (1): oil (25 mg); $[\alpha]^{25} \mathrm{D}+8.6^{\circ}$ (c 0.30, $\left.\mathrm{CHCl}_{3}\right) ; \mathrm{UV}(\mathrm{MeOH}) \lambda_{\max } \mathrm{nm}(\log \epsilon) 226$ (3.88), 290 (4.04); IR $(\mathrm{KBr}) v_{\max } 1735,1705,1235 \mathrm{~cm}^{-1} ;{ }^{1} \mathrm{H}$ and ${ }^{13} \mathrm{C}$ NMR, see Table 1; EIMS m/z $388[M]^{+}$(1), 345 (2), 331 (4), 257 (3), 231 (10), 201 (12), 173 (18), 146 (28), 131 (42), 109 (36), 55 (100); HREIMS m/z 388.2246 (calcd for $\mathrm{C}_{23} \mathrm{H}_{32} \mathrm{O}_{5}, 388.2251$ ).

Claviridenone F (2): amorphous solid (17 mg); $[\alpha]^{25} \mathrm{D}+6.7^{\circ}$ (c $0.31, \mathrm{CHCl}_{3}$ ); IR (KBr) $v_{\max } 1734,1708,1240 \mathrm{~cm}^{-1}$; UV $(\mathrm{MeOH}) \lambda_{\max } \mathrm{nm}(\log \epsilon) 224$ (3.89), 288 (4.06); ${ }^{1} \mathrm{H}$ and ${ }^{13} \mathrm{C} N \mathrm{NM}$,

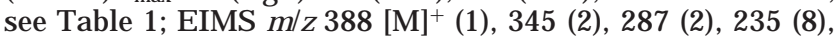
203 (9), 147 (15), 129 (26), 103 (26), 55 (100); HREIMS m/z 388.2248 (calcd for $\mathrm{C}_{23} \mathrm{H}_{32} \mathrm{O}_{5}, 388.2251$ ).

Claviridenone G (3): oil $(7 \mathrm{mg}) ;[\alpha]^{25} \mathrm{D}+5.4^{\circ}$ (c 0.10 $\mathrm{CHCl}_{3}$ ); UV (MeOH) $\lambda_{\max } \mathrm{nm}(\log \epsilon) 223$ (3.89), 286 (4.06); IR $(\mathrm{KBr}) v_{\max } 1738,1710,1230 \mathrm{~cm}^{-1} ;{ }^{1} \mathrm{H}$ and ${ }^{13} \mathrm{C}$ NMR, see Table 1; EIMS m/z 388 [M] ] (1), 346 (3), 329 (5), 235 (18), 203 (34), 109 (20), 55 (100); HREIMS m/z 388.2244 (calcd for $\mathrm{C}_{23} \mathrm{H}_{32} \mathrm{O}_{5}$, 388.2251). 
Stoloniferone E (4): amorphous solid (6 mg); $[\alpha]^{25} \mathrm{D}+10.0^{\circ}$ (c $0.05, \mathrm{CHCl}_{3}$ ); UV (MeOH) $\lambda_{\max } \mathrm{nm}(\mathrm{log} \epsilon) 222$ (3.79), 280 (4.01); IR (KBr) $v_{\max } 3300,1676 \mathrm{~cm}^{-1} ;{ }^{1} \mathrm{H}$ and ${ }^{13} \mathrm{C} N M R$, see Table 2; EIMS m/z 428 [M ] (1), 410 (2), 362 (1), 340 (2), 283 (2), 255 (5), 221 (5), 150 (100), 55 (86); HREI MS m/z 428.3299 (calcd for $\mathrm{C}_{28} \mathrm{H}_{44} \mathrm{O}_{3}, 428.3292$ ).

Stoloniferone F (5): amorphous solid (4 mg); $[\alpha]^{25} \mathrm{D}-30.6^{\circ}$ (c 0.11, $\mathrm{CHCl}_{3}$ ); UV (MeOH) $\lambda_{\max } \mathrm{nm}(\log \epsilon) 208$ (3.68); IR (KBr) $v_{\max } 3460,1680 \mathrm{~cm}^{-1} ;{ }^{1} \mathrm{H}$ and ${ }^{13} \mathrm{C}$ NMR, see Table 2; EIMS m/z 462 [M ]+ (1), 270 (1), 256 (1), 221 (1), 192 (3), 176 (5), 154 (45), 137 (100), 107 (66); HREIMS m/z 462.3342 (calcd for $\left.\mathrm{C}_{28} \mathrm{H}_{46} \mathrm{O}_{5}, 462.3347\right)$.

Stoloniferone G (6): amorphous solid (3 mg); $[\alpha]^{25}{ }_{D}-21.7^{\circ}$ (c $0.12, \mathrm{CHCl}_{3}$ ); IR (KBr) $v_{\max } 3510,1678 \mathrm{~cm}^{-1} ;{ }^{1} \mathrm{H}$ and ${ }^{13} \mathrm{C}$ NMR, see Table 2; EIMS m/z $460\left[\right.$ M] $^{+}$(1), 268 (1), 254 (1), 220 (1), 190 (4), 175 (6), 152 (40), 137 (100), 107 (76); HREIMS $\mathrm{m} / \mathrm{z} 460.3186$ (calcd for $\mathrm{C}_{28} \mathrm{H}_{44} \mathrm{O}_{5}, 460.3190$ ).

Claviolide (7): oil (80 mg); $[\alpha]^{25} \mathrm{D}-33.8^{\circ}$ (c $0.05, \mathrm{CHCl}_{3}$ ); UV (MeOH) $\lambda_{\max } \mathrm{nm}(\log \epsilon) 210$ (4.12); I R (KBr) $v_{\max } 1760,1730$, 1660, $1240 \mathrm{~cm}^{-1}$; ${ }^{1} \mathrm{H}$ NMR $\delta 1.69(3 \mathrm{H}, \mathrm{br} \mathrm{s}, \mathrm{H}-19), 1.73(3 \mathrm{H}, \mathrm{br}$ $\mathrm{s}, \mathrm{H}-20), 1.83(3 \mathrm{H}, \mathrm{br} \mathrm{s}, \mathrm{H}-18), 1.86(2 \mathrm{H}, \mathrm{m}, \mathrm{H}-14), 2.01(3 \mathrm{H}, \mathrm{s}$, $\left.\mathrm{OCOCH}_{3}\right), 2.03\left(3 \mathrm{H}, \mathrm{s}, \mathrm{OCOCH}_{3}\right), 2.09(1 \mathrm{H}, \mathrm{m}, \mathrm{H}-13 \beta), 2.16$

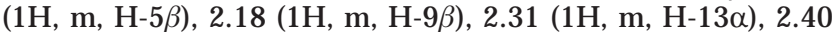
(1H, m, H-1), $2.60(1 \mathrm{H}, \mathrm{m}, \mathrm{H}-5 \alpha), 2.62(1 \mathrm{H}, \mathrm{m}, \mathrm{H}-9 \alpha), 4.84(1 \mathrm{H}$, $\mathrm{dd}, \mathrm{J}=4.0,9.0 \mathrm{~Hz}, \mathrm{H}-2), 5.02(1 \mathrm{H}, \mathrm{br} \mathrm{d}, \mathrm{J}=9.0 \mathrm{~Hz}, \mathrm{H}-3)$, $5.09(1 \mathrm{H}, \mathrm{br} d, \mathrm{~J}=8.5 \mathrm{~Hz}, \mathrm{H}-11), 5.15(1 \mathrm{H}, \mathrm{br} \mathrm{d}, \mathrm{J}=9.5 \mathrm{~Hz}$ $\mathrm{H}-7), 5.57(1 \mathrm{H}, \mathrm{m}, \mathrm{H}-6), 5.57(1 \mathrm{H}, \mathrm{d}, \mathrm{J}=2.0 \mathrm{~Hz}, \mathrm{H}-16), 5.71$ $(1 \mathrm{H}, \mathrm{m}, \mathrm{H}-10), 6.27(\mathrm{HH}, \mathrm{d}, \mathrm{J}=2.6 \mathrm{~Hz}, \mathrm{H}-16) ;{ }^{13} \mathrm{C} \mathrm{NMR} \delta 15.5$ (q, C-20), 16.3 (q, C-19), 19.9 (q, C-18), 21.3 (q, $\left.2 \times \mathrm{COCH}_{3}\right)$, 32.6 (t, C-14), 36.0 (t, C-13), 42.3 (t, C-5), 43.0 (d, C-1), $44.6(\mathrm{t}$, C-9), 67.4 (d, C-10), 69.1 (d, C-6), 78.9 (d, C-2), 122.3 (t, C-16), 124.2 (d, C-3), 125.1 (d, C-11), 126.8 (d, C-7), 137.7 (s, C-8), 139.1 (s, C-15), 139.9 (s, C-4), 141.0 (s, C-12), 170.0 (s, C-17), $170.3\left(\mathrm{~s}, 2 \times \mathrm{COCH}_{3}\right) ; \operatorname{EIMS~m} / \mathrm{z} 416[\mathrm{M}]^{+}(1), 356(8), 306$ (10), 296 (22), 153 (96), 135 (100); HEI MS m/z 416.2195 (calcd for $\mathrm{C}_{24} \mathrm{H}_{32} \mathrm{O}_{6}, 416.2199$ ).

Cytotoxicity Testing. P-388 cells were kindly supplied by Prof. J . M. Pezzuto, Department of Medicinal Chemistry and
Pharmacognosy, University of Illinois at Chicago; A549 and HT-29 were purchased from the American Type Culture Collection. Cytotoxic assays were carried out according to the procedure described previously. ${ }^{3}$

Acknowledgment. We thank Prof. J . M. Pezzuto, Department of Medicinal Chemistry and Pharmacognosy, College of Pharmacy, University of Illinois at Chicago, for the provision of P-388 cell lines. This work was supported by grants from the National Science Council of Taiwan awarded to C.-Y.D.

\section{References and Notes}

(1) (a) Kobayashi, M.; Yasuzawa, T.; Yoshihara, M.; Akutsu, H.; Kyogoku Y.; Kitagawa, I. Tetrahedron Lett. 1982, 23, 5331-5334. (b) Endo, M. Nskagawa, M.; Hamamoto, Y.; Nakanishi, T.J . Chem. Soc., Chem Commun. 1983, 12, 322-323. (c) Motomasa, K.; Lee, N. K.: Son, B. W.; Kyogoku, Y.; Y oshihara, K.; Kitagawa, I. Tetrahedron Lett. 1984, 51, 5925-5928. (d) Izac; R. R.; Fenical, W. Tetrahedron Lett. 1984, 25, 1325-1328. (e) I guchi, K.; Kaneta, S.; Mori, K.; Yamada, Y. Honda, A.; Mori, Y. Tetrahedron Lett. 1985, 26, 5787-5790. (f) Kobayashi, M.; Son, B. W.; Kyogoku, Y.; Kitagawa, I. Chem. Pharm. Bull. 1986, 34, 2306-2309. (g) I guchi, K.; Kaneta, S.; Mori, K.; Yamada, Y.; Honda, A.; Mori, Y.J . Chem. Soc., Chem. Commun. 1986, 12, 981-982. (h) Mori, K.; I guchi, K.; Yamada, N.; Yamada, Y. Tetrahedron Lett. $1987,28,5673-5676$ (i) I guchi, K.: Kaneta, S Mori, K.; Yamada, Y. Chem. Pharm. Bull. 1987, 35, 4375-4376. (j) I washima, M.; Matsumoto, Y.; Takahashi, H.; I guchi, K.J. . Nat. Prod. 2000, 63, 1647-1652. (k) I washima, M.; Nara, K.; I guchi, K. Steroids 2000,65, 130-137. (I) Yabe, T.; Yamada, T.; Shimomoura, M. Miyaoka, H.; Yamada, Y. J. Nat. Prod. 2000, 63, 433-435.

(2) Geran, R I.; Greenberg, N. H.; MacDonald, M. M.; Schumacher, A. M.; Abbott, B. J . Cancer Chemother. Rep. 1972, 3, 1-91.

(3) Hou, R.-S.; Duh, C.-Y.; Chiang, M. Y.; Lin, C.-N. J . Nat. Prod. 1995, $58,1126-1130$

(4) Kikuchi, H.; Tsukitani, Y.; I guchi, K.; Yamada, Y. Tetrahedron Lett. 1982, 49, 5171-5174

(5) I washima, M.; Nara, K.; I guchi, K. Steroids 2000, 65, 130-137.

(6) Kobayashi, M.; Lee, N. K.; Son, B. W.; Yanagi, K.; Kyogoku, Y.; Kitagawa, I. Tetrahedron Lett. 1984, 51, 5925-5928.

(7) Duh, C.-Y.; Chia, M.-C.; Wang, S.-K.; Chen, H.-J .; El-Gamal, A. A. H.; Dai, C.-F. J . Nat. Prod. 2001, 64, 1028-1031.

NP0201873 